\title{
Do as I Say, Not as They Do: Social Construction in the Epistle of Barnabas Through Canonical Interpretation and Ritual $^{*}$
}

\author{
Jason N. Yuh \\ University of Toronto; email: jason.n.yuh@gmail.com
}

\section{Abstract}

Scholars have not yet expounded on the importance and rationale of a key metaphor found in the Epistle of Barnabas: the circumcision of hearing (Barn. 9.1-3). In part, that is because the significance of this metaphor does not directly contribute to the theological outlook or background of Barnabas, which are topics that have largely preoccupied Barnabas scholarship. Yet, not only is this metaphor significant, but its significance lies in its social and communal implications. To explore these implications, I draw upon interdisciplinary research on canon and ritual. Research in these areas has independently demonstrated that canon and ritual are fundamental elements of any group, and I employ theoretical tools from these research areas to explain how Barnabas attempts to create and/or sustain his group by offering a new canon (or canonical interpretation) that could only be understood through the circumcision of hearing. Owing to the theoretical richness of canon and ritual, my study can also serve as a methodological template to examine the dynamics of other communal groups.

\footnotetext{
* An earlier version of this paper was presented at the Canadian Society of Biblical Studies at Ryerson University in 2017 ("Early Christianity, Early Judaism, and the Study of Religion" Seminar). I am thankful for the helpful feedback of Warren C. Campbell, Terence L. Donaldson, Gregory P. Fewster, John S. Kloppenborg, and the journal's anonymous reviewers and copyeditor. Above all, I thank my wife, Jeanie L. Yuh, for her overall support.
} 


\section{Keywords}

Epistle of Barnabas, ritual, canon, circumcision, social formation

\section{Introduction}

Scholars have not yet expounded on the importance and rationale of "the somewhat strangely" phrased metaphor found in the Epistle of Barnabas: the circumcision of hearing (Barn. 9.1-3). ${ }^{1}$ In part, that is because the significance of this metaphor does not directly contribute to the theological outlook or background of Barnabas, which are topics that have largely preoccupied Barnabas scholarship. ${ }^{2}$ Yet not only is this metaphor significant, but its significance lies in its social and communal implications.

To explore the social and communal implications, I draw upon interdisciplinary research on canon and ritual. Canon is a set of fundamental principles that simultaneously shapes and is shaped by the identity of a community, while rituals are the embodiment of these principles that, inter alia, differentiate the group from

\footnotetext{
${ }^{1}$ James N. Rhodes, The Epistle of Barnabas and the Deuteronomic Tradition: Polemics, Paraenesis, and the Legacy of the Golden-Calf Incident (WUNT 2/188; Tübingen: Mohr Siebeck, 2004) 59. Though very little has been written on the circumcision of hearing, the exceptional strangeness of the overall text itself has been well documented, e.g., Philipp Vielhauer, Geschichte der urchristlichen Literatur: Einleitung in das Neue Testament, die Apokryphen und die Apostolischen Väter (Berlin: de Gruyter, 1975) 612; James Carleton Paget, The Epistle of Barnabas: Outlook and Background (WUNT 2/64; Tübingen: Mohr Siebeck, 1994) 1; Jörg Frey, "Temple and Identity in Early Christianity and in the Johannine Community: Reflections on the 'Parting of the Ways," in Was 70 CE a Watershed in Jewish History? On Jews and Judaism Before and After the Destruction of the Second Temple (ed. Daniel R. Schwartz and Zeev Weiss; Leiden: Brill, 2012) 447-508, at 463; Ruth A. Clements, "Epilogue: 70 CE After 135 CE-The Making of a Watershed?" in Was 70 CE a Watershed? (ed. Schwartz and Weiss), 517-36, at 522; and Stephen G. Wilson, "Gentile Judaizers," NTS 38 (1992) 605-16, at 610. This strangeness has led to a negative view on the text (e.g., John Lawson, A Theological and Historical Introduction to the Apostolic Fathers [New York: Macmillan, 1961] 198), which has created the perception that the epistle "is not really worthy of the range of critical approaches applied to texts such as the NT" (Ken Derry, "One Stone on Another: Towards an Understanding of Symbolism in The Epistle of Barnabas," JECS 4 [1996] 515-28, at 516). English translations and verse references of the Epistle of Barnabas are from Bart D. Ehrman's critical edition (The Apostolic Fathers: Volume II [trans. Bart D. Ehrman; LCL 25; Cambridge: Harvard University Press, 2003] 1-84).

${ }^{2}$ There is a recent trend in exploring the social dimensions of this epistle (e.g., Michael Kok, "The True Covenant People: Ethnic Reasoning in the Epistle of Barnabas," SR 40 [2011] 81-97; Julien C. H. Smith, "The Epistle of Barnabas and the Two Ways of Teaching Authority," VC 68 [2014] 465-97; Derry, "One Stone on Another," 528). The emergence of these studies is indebted to the works of Carleton Paget and Hvalvik, as they remedied the prevalent view that Barnabas is merely a mindless motley of sources (Carleton Paget, Epistle of Barnabas; Reidar Hvalvik, The Struggle for Scripture and Covenant: The Purpose of the Epistle of Barnabas and Jewish-Christian Competition in the Second Century [WUNT 2/82; Tübingen: Mohr Siebeck, 1996]). Lastly, the socialscientific approach taken in this study functions as a response to Burton L. Mack's challenge for a "redescription of Christian origins" that is "firmly anchored in a social and cultural anthropology, capable of sustaining a conversation with the humanities" ("On Redescribing Christian Origins," MTSR 8 [1996] 247-69, at 254).
} 
outsiders while also structuring internal, hierarchical distinctions. Research in these areas has independently demonstrated that canon and ritual are fundamental elements of any group, and I employ theoretical tools from these research areas to explain how Barnabas attempts to create and/or sustain his group by offering the circumcision of hearing. ${ }^{3}$ More specifically, I argue that an examination of the metaphor illuminates how Barnabas sought to persuade his fledgling community to adhere uncompromisingly to his teachings by offering a new canon (or canonical interpretation, i.e., an interpretation that is asserted to be revelatory and therefore authoritative). ${ }^{4}$

Two features of Barnabas require discussion. First, it is because canon is indispensable for communities in general that Barnabas finds himself in a precarious argumentative stance: he seeks to refute "Jewish" traditions by using "Jewish" writings. ${ }^{5}$ Because Barnabas is unable to offer a new canon, he consequently offers a new canonical interpretation or $\gamma v \tilde{\omega} \sigma \iota \varsigma$ (knowledge) that can only be perceived when one's hearing is circumcised. Second, Barnabas's repudiation of most rituals once again leaves him in a tenuous situation when reflecting upon the fundamental role that rituals play for social groups. Upon closer analysis, however, various elements of the epistle are best explained when considering select concepts from ritual theories: Barnabas regards his hearers as fragile neophytes in the ambiguous phase of liminality. It is through the circumcision of hearing that Barnabas addresses both of these fundamental aspects of group formation, thereby helping his hearers

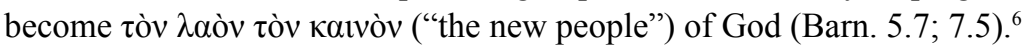

Owing to the theoretical richness of canon and ritual, my study can also serve as a methodological template to examine the dynamics of other communal groups beyond the one that Barnabas sought to establish and maintain. The most pertinent

\footnotetext{
${ }^{3}$ Recent utilization of canon and ritual as conceptual tools to analyze the communal aspects of early Christianity can be seen in Daniel Stökl Ben Ezra, "Weighing the Parts: A Papyrological Perspective on the Parting of the Ways," NovT 51 (2009) 168-86, and Risto Uro, Ritual and Christian Beginnings (Oxford: Oxford University, 2016). Through these tools, I am merely offering suggestive possibilities to what Barnabas was attempting to accomplish with his letter, especially with his use of the circumcision of hearing metaphor, while acknowledging that a misapplication of these tools could obscure some of the important distinctions of specific contexts.

${ }^{4}$ For an example in the Dead Sea Scrolls, see Hanne von Weissenberg and Elisa Uusimäki's study on how the interpretations of the Maskil and the pesharim are portrayed as equally revelatory and authoritative as texts that are later known to be biblical ("Are There Sacred Texts in Qumran? The Concept of Sacred Text in Light of the Qumran Collection," in Is There a Text in This Cave? Studies in the Textuality of the Dead Sea Scrolls in Honour of George J. Brooke [ed. Ariel Feldman, Maria Cioată, and Charlotte Hempel; STDJ 119; Leiden: Brill, 2017] 21-41; see also Philip S. Alexander, "Textual Authority and the Problem of the Biblical Canon at Qumran," in Is There a Text? [ed. Feldman, Cioată, and Hempel], 42-68).

${ }^{5}$ I use terms such as "Jew" and "Jewish" rather than "Judaean" (Anders Runesson, "Inventing Christian Identity: Paul, Ignatius, and Theodosius I," in Exploring Early Christian Identity [ed. Bengt Holmberg; Tübingen: Mohr Siebeck, 2008] 59-92, at 64-70).

${ }^{6}$ See also Smith, "Epistle of Barnabas," 468. Note the textual variant for 5.7 from the defective manuscripts of G (11th cent. and later).
} 
areas of research are the formation of early Christian identities and the contentious topic of early Jewish-Christian relations. Although the methodology and conclusion of this study are primarily concerned with the social dimensions of Barnabas, I do not intend to undermine the importance of the theology of Barnabas. Rather, my study aims to supplement, or perhaps even clarify, the theological outlook of Barnabas.

\section{Canonical Interpretation}

\section{A. Barnabas's Need for Canonical Interpretation}

Reidar Hvalvik observes that one of the key themes for Barnabas is his struggle for scripture. ${ }^{7}$ From a historical standpoint, the struggle is intense for the obvious reason that both Christ-devotees and Jews based their norms on the same sacred texts. For Barnabas, this struggle was acutely difficult as he (unlike Marcion) maintained a high regard for the Hebrew scriptures, and (unlike Justin Martyr, Origen, or Tertullian) contended that there was always only one people and covenant of God (e.g., Barn. 4.6). ${ }^{8}$ Thus, Barnabas distinguishes his authoritative $\gamma v \tilde{\omega} \sigma 1 \varsigma$ by denouncing the way that various strands of Judaism have understood these scriptural texts. ${ }^{9}$ Whether it is animal sacrifices (ch. 2; chs. 7-8), fasting (ch. 3), circumcision (ch. 9), dietary laws (ch. 10), the Sabbath (ch. 15), or the temple (ch. 16), the root of the problem is not what these sacred texts say about these things (e.g., 9.4; 10.1). Rather, the problem is that the sacred texts have been understood literally, a problem that is so egregious that it is of demonic influence (9.4). ${ }^{10}$

\section{B. Canon as a Prerequisite for Group Identity}

In order more fully to appreciate Barnabas's predicament in this regard, it is helpful to note that there is an inextricable - and inevitable - connection between canon and group formation, as recently established by numerous scholars from varying areas of study. ${ }^{11}$ For the purpose of this study, canon operates simply as a finite set of

${ }^{7}$ Hvalvik, Struggle for Scripture.

${ }^{8}$ For example, Rhodes, Epistle of Barnabas, 178-82; Hvalvik, Struggle for Scripture, 91-92.

${ }^{9}$ In older scholarship, a distinction was made between two kinds of $\gamma v \tilde{\omega} \sigma 1 \varsigma$ in the epistle (e.g., Hans Windisch, Der Barnabasbrief [HNT Ergänzungsband, Apostolischen Väter, 3; Tübingen: Mohr, 1920] 307-9; Robert A. Kraft, Barnabas and the Didache [vol. 3 of The Apostolic Fathers: A New Translation and Commentary; ed. Robert M. Grant; New York: Nelson, 1964] 22-27). For a detailed summary of this view, see Carleton Paget, Epistle of Barnabas, 46-49. I am following more recent studies by interpreting $\gamma v \tilde{\sigma} \sigma 1 \zeta$ as conveying the same meaning throughout the epistle (e.g., Jonathan A. Draper, "Barnabas and the Riddle of the Didache Revisited," JSNT 17 [1995] 89-113, at 95; Hvalvik, Struggle for Scripture, 84-86).

${ }^{10}$ Although, there are portions of the text where these sacred texts are to be understood literally, e.g., Daniel C. Ullucci, The Christian Rejection of Animal Sacrifice (New York: Oxford University Press, 2012) 97. For a dedicated study on 9.4, see James Carleton Paget, "Barnabas 9:4: A Peculiar Verse on Circumcision," VC 45 (1991) 242-54.

${ }^{11}$ Pertaining to early Christianity in particular, see Guy G. Stroumsa, "Early Christianity-A 
basic principles (or convictions, axioms, core narratives) that plays an authoritative role for, and is shaped by, a group. ${ }^{12}$ The very existence of a canon-its inception, maintenance, relevance, and interpretation - is thus predicated upon its group. However, the inverse is equally true: the very existence of a group is predicated upon its canon. A group cannot be considered as such unless its individual members share at least some common principles that they perceive as normative or canonical. Canon, however, does not entail fixity or precision. Especially in a discipline where canon is often conflated with the Bible or distorted by "bibliographic" concepts, it is critical to make a distinction between a theoretical canon that was functional based on communal reception/practice and an anachronistic canon that assumes ideas that skew our perspective into this ancient period. ${ }^{13}$ In this essay, canon is used only in the former sense.

Closely related to the critical role that canon plays within a community is the need for interpreters. ${ }^{14}$ These interpreters are individuals within a community whose

Religion of the Book?" in Homer, the Bible, and Beyond: Literary and Religious Canons in the Ancient World (ed. Margalit Finkelberg and Guy G. Stroumsa; Leiden: Brill, 2003) 153-74, at 153; Christoph Markschies, "The Canon of the New Testament in Antiquity," in Homer, the Bible, and Beyond, 175-94, at 192; David Brakke, "A New Fragment of Athanasius's Thirty-Ninth Festal Letter: Heresy, Apocrypha, and the Canon," HTR 103 (2010) 47-66; David Brakke's article, published more than twenty years ago, receives special mention as it is perhaps the earliest study to explore the "social and political implications" of the concept of canon ("Canon Formation and Social Conflict in Fourth-Century Egypt: Athanasius of Alexandria's Thirty-Ninth 'Festal Letter,'” HTR 87 [1994] 395-419, at 396), and also for his own application of Jonathan Z. Smith's cross-cultural findings (ibid., 416). At a more general level, see Jonathan Z. Smith, Imagining Religion: From Babylon to Jonestown (Chicago: University of Chicago Press, 1982) 36-52; Miriam Levering, "Introduction," in Rethinking Scripture: Essays from a Comparative Perspective (ed. Miriam Levering; Albany: SUNY Press, 1989) 1-17, at 5; Margalit Finkelberg and Guy G. Stroumsa, "Introduction: Before the Western Canon," in Homer, the Bible, and Beyond, 1-8, at 5; Markschies, "Canon of the New Testament," 178; Guy G. Stroumsa, Hidden Wisdom: Esoteric Traditions and the Roots of Christian Mysticism (rev. ed.; SHR 70; Leiden: Brill, 2005) 88; Aleida Assmann, "Canon and Archive," in Cultural Memory Studies: An International and Interdisciplinary Handbook (ed. Ansgar Nünning, Astrid Erll, and Sara B. Young; Berlin: de Gruyter, 2008) 97-107, at 100.

${ }^{12}$ Similar to Finkelberg and Stroumsa's notion of "foundational texts" ("Introduction," 5).

${ }^{13}$ On textual pluriformity and the lack of fixity in early Judaism, see Alexander, "Textual Authority"; Judith H. Newman, Before the Bible: The Liturgical Body and the Formation of Scriptures in Early Judaism (Oxford: Oxford University Press, 2018). On anachronistic assumptions in studies related to canon, see Eva Mroczek, The Literary Imagination in Jewish Antiquity (New York: Oxford University Press, 2016). On the distinction between a theoretical and an anachronistic canon, see Stephen B. Chapman, "Collections, Canons, and Communities," in The Cambridge Companion to the Hebrew Bible/Old Testament (ed. Stephen B. Chapman and Marvin A. Sweeney; New York: Cambridge University Press, 2016) 28-54, at 35-36; Alexander, "Textual Authority," 51.

${ }^{14}$ This touches upon the inseparable relationship between canon and hermeneutics as seen across different cultures, such as the Neoplatonists, Rabbinic Jewish communities (Finkelberg and Stroumsa, "Introduction," 6-7), and religious groups of ancient Rome (Mary Beard, "Ancient Literacy and the Function of the Written Word in Roman Religion," in Literacy in the Roman World [ed. Mary Beard et al.; JRA Supplementary Series 3; Ann Arbor: Journal of Roman Archaeology, 1991] 35-58, at 53-58; though Beard's emphasis is on written texts and not canon per se). See also Stroumsa's observation concerning the parallel between the Mishnah and the New Testament (Hidden Wisdom, 
interpretations on what various principles mean and how they can be applied are considered to be authoritative or canonical. As Jan Assmann remarks:

\begin{abstract}
In this way interpretation becomes the central principle of cultural coherence and identity. The normative and formative impulses of cultural memory can only be gleaned through the incessant, constantly renewed textual interpretation of the tradition through which identity is established. Interpretation becomes the gesture of remembering, the interpreter becomes a person who remembers and reminds us of a forgotten truth. ${ }^{15}$
\end{abstract}

If the identity of a group is established through "renewed" interpretations of sacred traditions and/or texts, then this explains the social reasons behind why Barnabas, and many other early "Christian" writers, would have been so preoccupied with scriptural texts. The stories of Jesus compelled individuals to create these contemporary interpretations. Those who agreed with these interpretations eventually formed their own subgroups. As differences of interpretations became intolerable, the need for a subgroup to become its own group necessitated a change in canon — or, in Barnabas's situation, the interpretation of scripture. ${ }^{16}$

Thus, Barnabas created a new community by offering new interpretations of writings that were deemed authoritative or normative at the time. This delicate balance meant that Barnabas could not introduce new texts that were explicitly about Jesus, but was required to interpret Jesus into the existing sources that were already authoritative. ${ }^{17}$ In other words, Barnabas needed "to develop exegetical procedures that will allow the canon to be applied without alteration or, at least,

79-91; The Making of the Abrahamic Religions in Late Antiquity [Oxford Studies in the Abrahamic Religions; Oxford: Oxford University Press, 2015] 31-32).

${ }^{15}$ Jan Assmann, Religion and Cultural Memory: Ten Studies (Stanford, CA: Stanford University Press, 2006) 43. Assmann grounds these assertions primarily in evidence from ancient Egyptian culture and, interacting with Leo Oppenheim, ancient Mesopotamian culture. Assmann's statements are even more relevant for the "textual communities" of early Christianity (Judith Lieu, Christian Identity in the Jewish and Graeco-Roman World [Oxford: Oxford University Press, 2004] 28-29). See also Smith, Imagining Religion, 49 and Harald Welzer, "Communicative Memory," in Cultural Memory Studies (ed. Nünning, Erll, and Young), 285-98. For an example in early Judaism, see n. 4 above.

${ }^{16}$ For example, George W. E. Nickelsburg, "Revealed Wisdom as a Criterion for Inclusion and Exclusion: From Jewish Sectarianism to Early Christianity," in "To See Ourselves as Others See Us": Christians, Jews, "Others" in Late Antiquity (ed. Jacob Neusner and Ernest S. Frerichs; Chico, CA: Scholars Press, 1985) 73-92; however, Shaye J. D. Cohen places the emphasis on the temple and who is true Israel (Shaye J. D. Cohen, From the Maccabees to the Mishnah $\left[2^{\text {nd }}\right.$ ed.; Louisville: Westminster John Knox, 2006] 119-66); but even topics concerning the temple and true Israel would have been based on competing interpretations of scripture (ibid., 129).

${ }^{17}$ Some scholars suggest that there were "foundational texts" that were authoritative over most Jewish communities during this time (Bruce M. Metzger, The Canon of the New Testament: Its Origin, Development, and Significance [rev. ed.; Oxford: Clarendon Press, 1997] 2) or that "by the end of the first century CE there was a canon that most Jews accepted" (Timothy H. Lim, The Formation of the Jewish Canon [New Haven: Yale University Press, 2013] 180). The point, however, is that Barnabas relies heavily on Jewish sources and very little on Christian ones (Metzger, Canon of the New Testament, 58-59; James Carleton Paget, "Paul and the Epistle of Barnabas," NovT 38 [1996] 359-81). For a detailed study of Barnabas's source, see Carleton Paget, Epistle of Barnabas. 
without admitting to alteration." 18 For instance, Barnabas construes covenantal faithfulness as being grounded not upon physical practices, but upon true $\gamma v \tilde{\omega} \sigma ı$ that enables one to "know the commandments in an upright way" (10.12). In other words, the problem with "them" is that they have misunderstood scripture; hence, the solution is the right interpretation of scripture through the disclosure of Barnabas's $\gamma \nu \tilde{\omega} \sigma ı \varsigma^{19}{ }^{19}$ Consequently, this interpretation becomes the new "canon" around which Barnabas's group can form. Borrowing the terminology of J. Z. Smith, Barnabas is assuming the role of the group's "hermeneute."20

\section{Barnabas as the "Hermeneute" with $\Gamma v \tilde{\omega} \sigma l \varsigma$}

By virtue of having $\tau \varepsilon \lambda \varepsilon i ́ \alpha \gamma \nu \tilde{\omega} \sigma ı \varsigma$ (perfect knowledge) and his desire to disseminate it, Barnabas establishes himself as the group's "hermeneute" from the outset (1.5), a point which he strongly and proportionally develops throughout the letter. Barnabas assumes his pedagogical role and his possession of $\tau \varepsilon \lambda \varepsilon i ́ \alpha \gamma \nu \tilde{\omega} \sigma 1 \varsigma$ in virtually every chapter (e.g., 1.5, 8; 4.6; 6.9; 7.1; 8.2; 9.7, 9; 10.11; 12.3, 8; 14.4; 15.5; 16.7, 8; ch. $17 ; 18.1)$, and he implicitly reinforces this role with the concentrated integration of Jewish traditions into his arguments. ${ }^{21}$

There is also evidence that Barnabas is writing in response to contemporaneous events, prompting him to write with urgency (e.g., 1.5, 8; 2.1, 10; 4.1-2, 6, 9-10; $16.4,5) . \Gamma v \tilde{\omega} \sigma \mathrm{s} \varsigma$ in this way works as the cipher that allows Barnabas and his hearers to make proper sense of what is currently transpiring (1.7; 5.3). Barnabas

${ }^{18}$ Smith, Imagining Religion, 50. See also Bernard M. Levinson's helpful nuances to Smith's theoretical model: the exegetical innovation is hidden and the canon does not need to be closed (Legal Revision and Religious Renewal in Ancient Israel [Cambridge: Cambridge University Press, 2008] 15-18).

${ }^{19}$ So Draper, "Barnabas and the Riddle," 95; Hvalvik, Struggle for Scripture, 85.

${ }^{20}$ Smith, Imagining Religion, 48. While canon and group formation can be understood within the conversation concerning the relationship between "social formation and mythmaking," this paper will not attempt to explore the "social logic" of this epistle. For a short summary on this conversation, see Ron Cameron and Merrill P. Miller, "Conclusion: Redescribing Christian Origins," in Redescribing Christian Origins (ed. Ron Cameron and Merrill P. Miller; Atlanta: SBL Press, 2004) 497-516, at 513-15.

${ }^{21}$ On the inextricable connection between Barnabas and Jewish traditions, see Daniel Stökl Ben Ezra who notes that Barnabas represents "the text best informed about the Temple rite [of Yom Kippur]" and is therefore a "goldmine of Jewish traditions" ("Fasting with Jews, Thinking with Scapegoats: Some Remarks on Yom Kippur in Early Judaism and Christianity, in Particular 4Q541, Barnabas 7, Matthew 27 and Acts 27," in The Day of Atonement: Its Interpretations in Early Jewish and Christian Traditions [ed. Thomas Hieke and Tobias Nicklas; TBN 15; Leiden: Brill, 2012] 165-88, at 173-74). Also James D. G. Dunn suggests that other than 1 Clement, the Epistle of Barnabas uses the Hebrew scripture more heavily than any other early Christian writing at this time (Neither Jew nor Greek: A Contested Identity [Grand Rapids: Eerdmans, 2015] 550-69). See also Pierluigi Lanfranchi, "Attitudes to the Sabbath in Three Apostolic Fathers: Didache, Ignatius, and Barnabas," in Jesus, Paul, and Early Christianity: Studies in Honour of Henk Jan De Jonge (ed. Rieuwerd Buitenwerf, Harm W. Hollander, and Johannes Tromp; NovTSup 130; Leiden: Brill, 2008) 243-60; Tim Hegedus, "Midrash and the Letter of Barnabas," BTB 37 (2007) 20-26; L. W. Barnard, "The 'Epistle of Barnabas' and Its Contemporary Setting," $A N R W$ II.27.1 (1993) 159-207. 
is therefore assuming "the indigenous theologian's task," the task to interpret and apply the Jewish sacred traditions to the specific circumstances and concerns of his community. ${ }^{22}$ Once again, a canon is not a canon unless it is being animated within the triangular relationship between itself, interpreter, and listener. ${ }^{23}$

Even the Two Ways tradition (Barn. 18-21), which concludes the epistle, is portrayed as another form of teaching (from the lemma $\delta 1 \delta \alpha \chi \eta$; 18.1). Moreover, the way of the righteous is described as a way of $\gamma v \tilde{\omega} \sigma ı \varsigma(19.1 ; 21.5-6) .{ }^{24}$ Therefore, more than any other role, Barnabas presents himself as the "hermeneute" who has divine $\gamma v \tilde{\omega} \sigma 1 \varsigma$, which not only legitimizes his truth claims, but also his efforts to simultaneously create a new community and a new canon. ${ }^{25}$ However, Barnabas's $\gamma v \tilde{\omega} \sigma ı \zeta$ is controversial, and there are indications that his hearers might not accept parts of it. ${ }^{26}$ It is thus the circumcision of hearing that provides his hearers the requisite ability to properly understand and believe his teachings.

\section{The Need for the Circumcision of Hearing}

Our analysis of Barnabas's circumcision of hearing $(8.7 ; 9.3 ; 10.12 ; 16.10$; see also 11.11$)^{27}$ begins with the possible influences behind the metaphor. Although the


["he circumcised our hearing"], 9.3; see also 10.12) does not occur in any prior writing, the underlying concept can be traced to Jeremiah 6:10 (LXX: $\alpha \pi \varepsilon \rho i ́ \tau \mu \eta \tau \alpha$ $\tau \grave{\alpha} \tilde{\omega} \tau \alpha \alpha \dot{\tau} \tau \tilde{\omega} v$ ["their ears are uncircumcised"]). ${ }^{28}$ Additionally, this metaphor

${ }^{22}$ Smith, Imagining Religion, 46, 51.

${ }^{23}$ See also Assmann, "Canon and Archive," 100.

${ }^{24}$ See also Hvalvik, Struggle for Scripture, 86.

${ }^{25}$ See also Smith, "Epistle of Barnabas," 486-89. For more on the role of the teacher, see $n$. 51 below.

${ }^{26}$ Smith, "Epistle of Barnabas," 488; Hvalvik, Struggle for Scripture, 53. It will be shown later in this article that the uncertainty lies not in the content of Barnabas's teaching, but in the condition of his hearers.

${ }^{27}$ Though the idea of hearing is also found in 12.8 , these four verses will be primarily examined because they all convey the notion of differentiation that is also seen in the literal circumcision. For instance, these verses not only include the idea of hearing, but they (or their respective contexts) also imply the covenantal implications of circumcision (e.g., 9.6) by making a contrast between those who hear and those who do not hear. On the other hand, 12.8 only references the notion of hearing without making a distinction between those who are in and out of the covenant. A lexical search would also return references such as 7.3 and 13.2, but the sense of $\dot{\alpha} \kappa o v ́ \omega$ (I hear) in these are idiomatic and should not be taken in a technical way (e.g., "consider this"). Also, 9.3's circumcision of hearing is actually placed in 9.4 in some editions (e.g., The Apostolic Fathers: Greek Texts and English Translations [ed. and trans. Michael W. Holmes; rev. ed.; Grand Rapids: Baker Books, 2007] 406).

${ }^{28}$ The LXX translation is from the author, but all other scriptural translations are from the NRSV.

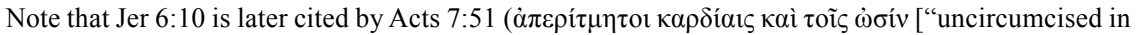
heart and ears"]). Also, there are instances of "circumcision" and "hearing" in Herodotus, but these are not related to circumcision in the Jewish cultic sense (e.g., Hist. 2.162.5: $\pi \varepsilon \rho \imath \tau \alpha \mu \varepsilon i ̃ v ~ \pi \rho o \sigma \tau \alpha \dot{\xi} \alpha$ l

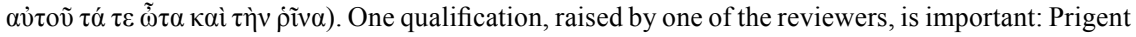
and Kraft see two additional references to circumcision of hearing in Barn. 9.1 (following P and L rather than $\mathrm{S}$ and $\mathrm{H}$ ). The first additional reference is not a quotation, but the second would be from 
would not have been uncommon in Hellenistic Judaism: "This type of approach [linking disobedience with hearing] was extended especially to the thought of life . . . in the Judaism represented by Philo - circumcision of the understanding (ear, heart) thus became prime for him [Philo]." ${ }^{29}$ Kraft is right to group ear and heart together, because nowhere does Philo actually combine (un)circumcision with ears or hearing. However, Philo does make a cryptic reference to the circumcision of the eyes. ${ }^{30}$ The faculties of seeing and hearing are often coupled together for Philo as they are "the lordliest of the senses" (Spec. 1.193) or the philosophical senses (QG 3.5). ${ }^{31}$ So, although the exact phrase is not found in Philo's extant writings, the general notion is certainly there. Perhaps more indicative of a Hellenistic influence on Barnabas is how Philo famously rebukes those who "repeal the law laid down for circumcising" (Migr. 92). This would imply that within Philo's circles, which likely included other Hellenistic Jews who had the penchant for allegorizing, there were those who would have understood circumcision in the same way as Barnabas. If it were not for the historical distance between Philo and Barnabas, it would be reasonable to presume that Philo was speaking of Barnabas. ${ }^{32}$

Jer 4:4. Even if one favors P and L, Prigent and Kraft acknowledge that the linguistic metaphor would not have originated from Jer 4:4: "the citation is strongly reworked to better fit the collection" (Épître de Barnabé [ed. and trans. Pierre Prigent and Robert A. Kraft; SC 172; Paris: Cerf, 1971] 142 n. 2: la citation est fortement remaniée pour mieux s'adapter au florilège).

${ }^{29} \mathrm{Kraft}$, Barnabas and the Didache, 106. Note that Kraft interprets the letter in general as a collection of pre-existent sources. As indicated in n. 2, this assumption has been rightly qualified. Hvalvik writes that "the author's material is traditional; his use of the material, however, is often original" (Hvalvik, Struggle for Scripture, 330) as the letter in general discloses a coherent purpose, namely the right interpretation of scripture (102-36) and the distinction between two peoples or ways (ibid., 137-57). See also Carleton Paget, Epistle of Barnabas, 2, 258-60; idem, "Barnabas 9:4."

30 "And when the mind is circumcised and contains only necessary and useful things, and when at the same time there is cut off whatever causes pride to increase, then with it are circumcised the eyes also, as though they could not (otherwise) see" ( $Q G$ 3.47). All texts and translations of Philo's writings throughout are from Philo (trans. G. H. Whitaker, F. H. Colson, and Ralph Marcus; 12 vols.; LCL 226, 227, 247, 261, 275, 289, 320, 341, 363, 379, 380, 401; Cambridge: Harvard University Press, 1929-1962).

${ }^{31}$ Philo typically groups seeing and hearing together (Migr. 103, 119; Spec. 1.29, 337, 342), which are inferior to "the rational" faculties of "mind and speech," but higher than smell and taste ( $Q G$ 3.5). Hearing, however, is secondary to seeing (Migr. 49-52; $Q G 3.32,59)$. The next closest writing to the circumcision of hearing or ears by Philo besides $Q G 3.47$ would be: "For he who listens with the tips of his ears is able to get (only) a somewhat vague perception of what is said, while to him who listens carefully the words enter more clearly and the things heard travel on all the paths so that they form his mind with deep impressions, as if (it were) wax, lest it easily become stupid and (the impressions) leap away" ( $Q E$ 2.13). However, in this quote, he is not suggesting that the tips of the ears need to be circumcised. Lastly, it should be noted that Barnabas's metaphor differs in significant ways from Philo's famous treatment on circumcision (Spec. 1.1-11). Whereas Barnabas's focus on his metaphorical circumcision is primarily hermeneutical, Philo's is more diverse (e.g., healing from "anthrax or carbuncle" [1.4], cleanliness [1.5], "fertility of offspring" [1.7], "the excision of pleasures" [1.9]) and presupposes the literal practice of circumcision (so John M. G. Barclay, "Paul and Philo on Circumcision: Romans 2.25-29 in Social and Cultural Context," NTS 44 [1998] 536-56, at 538-40).

${ }^{32}$ See also Carleton Paget, "Paul and the Epistle of Barnabas," 378; idem, "Barnabas 9:4," 245. 
All four of the allusions to the circumcision of hearing are placed at pivotal positions within Barnabas's overall argument $(8.7 ; 9.3 ; 10.12 ; 16.10)$. As mentioned earlier, Barnabas opens his letter with his claim of divine $\gamma v \tilde{\omega} \sigma ı \varsigma$ (1.5), which he demonstrates by reproving one Jewish practice after another. Hence, 1.1 to 8.6 is more or less a denunciation of Jewish ancestral customs. Such a radical assertion might raise the question for his hearers: how can so many practicing Jews, who have been perceived as being faithful to the covenant based on these specific practices, be so misled? According to Barnabas, such insights are "obscure to

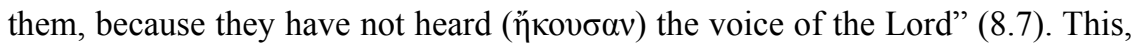
of course, raises yet another question: if scriptural insights are "obscure to them" fundamentally "because they have not heard the voice of the Lord" (8.7), then what enables Barnabas and his hearers to hear properly? Barnabas attempts to answer this question in the ensuing argument on circumcision proper (ch. 9). Thus, 8.7 has two functions. Barnabas simultaneously concludes his previous arguments (1.1-8.6) while introducing his next argument on the circumcision of hearing (ch. 9). ${ }^{33}$

Barnabas provides a rather facile answer: the Lord "circumcised ( $\pi \varepsilon \rho \iota \varepsilon \dot{\tau \varepsilon \mu \varepsilon v)}$


(9.3), thereby affording them eternal life (9.2). Circumcision of hearing is, therefore, the critical difference between "us" and "them" as indicated by the iv $\alpha$

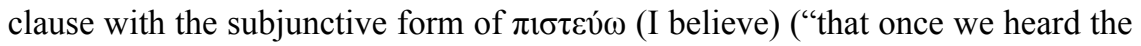

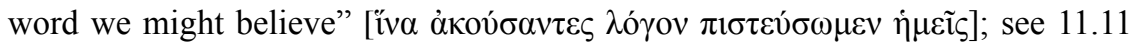
for a similar correlation). Just as literal circumcision was the sign of the covenant, so is the epistemological circumcision that Barnabas is advocating. Barnabas

\footnotetext{
Additionally, the broad Hellenistic influence may have in part inspired Barnabas to view the entirety of Jewish law figuratively. To continue Philo's quotation, there were certainly those in Philo's circle that neglected "the sanctity of the Temple and a thousand other things" (Migr. 92). Heikki Räisänen suggests that certain strands within Hellenistic Judaism were not only abandoning their hopes for the physical restoration of the temple, but possibly eschewing the practice of literal circumcision (Jesus, Paul and Torah: Collected Essays [JSOTSup 43; Sheffield: JSOT Press, 1992] 149-202); see also Daniel R. Schwartz, Studies in the Jewish Background of Christianity (WUNT 60; Tübingen: Mohr Siebeck, 1992) 10-19.

${ }^{33}$ The failure to trace how 8.7 is connected to the previous chapters, and ultimately to the very beginning of the letter, is one of the reasons that the circumcision of hearing has not received sustained analysis up until now. Most commentators see 8.7 as merely an introduction to ch. 9, which is concluded with 10.12 (e.g., Carleton Paget, Epistle of Barnabas, 149; Hvalvik, Struggle for Scripture, 184). However, Julien Smith sees that it is also connected to 3.6, while still being used to transition into ch. 9 ("Epistle of Barnabas," 477-89). Though not explicit, Rhodes implies what I am arguing, that the "main point" is the "capacity to understand and respond appropriately to the divine will," which are ideas that have been introduced from the very beginning of the letter (Epistle of Barnabas, 59). See also Klaus Wengst, Tradition und Theologie des Barnabasbriefes (Arbeiten Zur Kirchengeschichte 42; Berlin: de Gruyter, 1971) 34-35, 78; Ferdinand R. Prostmeier, Der Barnabasbrief (Kommentar zu den Apostolischen Vätern 8; Göttingen: Vandenhoeck \& Ruprecht, 1999) $331,352-53$.
} 
substantiates his assertion by including a cluster of scriptural citations (9.1-5), ${ }^{34}$ refuting hypothetical counterarguments (9.6-7), and generously disclosing his most "reliable lesson," which explains why Abraham and his household were nevertheless circumcised (9.8-9).

Although Barnabas introduces a new topic in the next chapter (i.e., dietary laws in ch. 10), his argumentative strategy is consistent. That is, people fail to acknowledge his $\gamma v \tilde{\omega} \sigma ı \varsigma$ concerning dietary laws because their hearing has not been circumcised (10.12). The syntactical repetition of iv $\alpha$ followed by a subjunctive verb ("that we may understand these things" [i๊ $\alpha \sigma \sigma v i \tilde{\omega} \mu \varepsilon v \tau \alpha \tilde{v} \tau \alpha]$ ) that we read in 9.3 reinforces the causal significance of this circumcision. Furthermore, referring to the circumcision of hearing at this juncture reveals that the relevance of the metaphor is not limited to his discussion on literal circumcision (ch. 9). This is precisely how Clement of Alexandria, whose work has been considered "the best commentary on Barnabas," 35 later cites this metaphor in his own discussion on true knowledge (Strom. 5.8.51.6 cites Barn. 10.12). ${ }^{36}$ Indeed, Clement makes the connection between knowledge and the circumcision of hearing by including the accompanying subjunctive clause, iv $\alpha \alpha \sigma v v i \tilde{\omega} \mu \varepsilon v \tau \alpha \tilde{v} \tau \alpha{ }^{37}$ As we saw in 8.7 , the metaphor not only explains the erroneous practices of chapters $1-8$, but also the dietary laws of chapter 10 .

Circumcision of hearing, therefore, allows an individual truly to hear. This, then, enables one to have proper understanding $(10.12),{ }^{38}$ the ability to believe (9.3), and the privilege of everlasting life (9.2). All of these effects are assumed in

${ }^{34}$ To be exact, "9:1-3 alone contains eight short quotations concerning 'hearing' and 'ears" " (Robert A. Kraft, "The Epistle of Barnabas: Its Quotations and Their Sources" [PhD diss., Harvard University, 1961] 43).

${ }^{35} \mathrm{Kraft}$, Barnabas and the Didache, 45. Clement's high regard for Barnabas has been welldocumented: Carleton Paget notes that Clement explicitly cites Barnabas eight times in the Stromateis (Jews, Christians and Jewish Christians in Antiquity [WUNT 251; Tübingen: Mohr Siebeck, 2010] 95 n. 23); see also Didache (Apostellehre); Barnabasbrief; Zweiter Klemensbrief; Schrift an Diognet (ed. and trans. Klaus Wengst; Schriften des Urchristentums 2; Munich: Kösel, 1984) 106; Ehrman, "Epistle of Barnabas," 3, 7.

${ }^{36}$ References to the Stromateis follow the critical edition of Otto Stählin, in Clemens Alexandrinus (ed. Otto Stählin; 4 vols.; rev. ed.; GCS 12, 15, 17, 39; Berlin: Akademie-Verlag, 1960).

${ }^{37} \mathrm{Clement}$ 's epistemological usage of this metaphor is all the more remarkable when considering that his extant writings reveal his overarching concern with knowledge (Eric Osborn, Clement of Alexandria [Cambridge: Cambridge University Press, 2005] xiii, 1-4; Andrew C. Itter, Esoteric Teaching in the Stromateis of Clement of Alexandria [Supplements to VC 97; Leiden: Brill, 2009] 81). Interestingly, scholars have used ritualized language to describe how the pursuit of knowledge is one of the primary purposes of the Stromateis, e.g., "to initiate souls into the true philosophy of Christ and to have knowledge of the first principle of the universe" (Itter, Esoteric Teaching, 109); "the initiation into true gnosis" (Louis Roberts, "The Literary Form of the Stromateis," SCe 1 [1981] 211-22, at 213). That this chapter (Strom. 5.8) is specifically concerned with knowledge is apparent in Clement's use even of the barbarians as examples of ones who employ the use of symbols $(5.8 .44 .1,45.1)$, and how he cites Theognis 35-36 (5.8.52.4) and Isa 1:3 (5.8.54.1).

${ }^{38}$ For the same analysis on 9.1-3, see Prostmeier, Barnabasbrief, 352-53. 
Barnabas's discussion regarding one of the primary themes of the letter, the temple. ${ }^{39}$ Barnabas assumes that those who have access to the true temple are those who have proper understanding of and the ability to believe God's "word of faith ... the wisdom of his upright demands, the commandments of the teaching" (16.9).

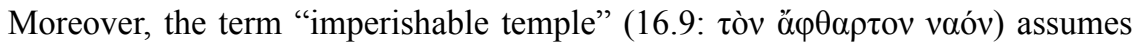
that such inhabitants have everlasting life. What transpires at this temple is "a 'gnostic' reading of Scripture" that is made possible only through the circumcision of hearing, otherwise such a "reading" would be "obscure to them" (8.7). ${ }^{40}$ Hence, when Barnabas describes this interaction, the emphasis is on speech and hearing: "For the one who longs to be saved looks not merely to a person but to the one who dwells and speaks in him. For he is amazed at him since he has never heard

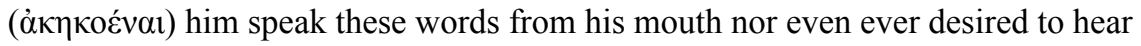

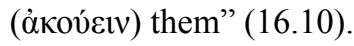

Chapter 16, however, is not exclusively about the temple. It is the natural culmination of the preceding arguments about the people (ch. 13), the covenant (ch. 14; also ch. 4), and the Sabbath (ch. 15). Rather than "they" who practice the literal interpretations of scripture (ch. 13) on the Sabbath (ch. 15) under the assumption of their broken, nullified covenant (ch. 14; also ch. 4), it is "we" who will celebrate the true Sabbath (i.e., the eighth day, 16.6), in the spiritual temple in which God's voice is directly heard (16.10). In this way, the image of the spiritual temple is a convergence of both of these social principles: canonical interpretation (i.e., the

${ }^{39}$ On the temple being one of the primary themes of Barnabas, see Rhodes, Epistle of Barnabas, 81; Stephen G. Wilson, Related Strangers: Jews and Christians, 70-170 C. E. (Minneapolis: Fortress, 1995) 131-36; Martin B. Shukster and Peter Richardson, "Temple and Bet Ha-midrash in the Epistle of Barnabas," in Anti-Judaism in Early Christianity (ed. Stephen G. Wilson; 2 vols.; Studies in Christianity and Judaism 2-3; Waterloo: Wilfrid Laurier University, 1986) 2:17-32.

${ }^{40}$ Barnabé (ed. Prigent and Kraft), 195 n. 2: Une lecture " gnostique " de l'Écriture. 
voice of God in 16.10) and ritual (i.e., the eighth day in 16.6).$^{41}$ Hence, the distinction between the two, as it will be further demonstrated below, is merely heuristic. ${ }^{42}$

In sum, the circumcision of hearing is a motif that plays the prerequisite role for the theme that governs the whole epistle: $\tau \varepsilon \lambda \varepsilon i ́ \alpha \gamma \nu \tilde{\omega} \sigma ı, \zeta$, which is referenced as Barnabas's only competitive advantage against his rival teachers. Without this circumcision, Barnabas's claim to $\gamma \nu \tilde{\omega} \sigma 1 \zeta$ is meaningless. As we have seen with the emphasis on canon, Barnabas's failure to convince others of his canonical interpretation is his failure to create his own community. However, Barnabas's metaphor is not merely an analogy, because the metaphor plays a critical role in other parts of the letter. More specifically, it functions as some sort of ritual for Barnabas and should therefore be understood in the same way in which "they" believed that physical circumcision was the seal of their covenant (9.6). ${ }^{43}$ Circumcision of hearing is therefore the initiatory rite of the covenant for Barnabas and his hearers (8.7; 9.3). As Martin B. Shukster and Peter Richardson note: "The covenantal sign of Christian exegesis is the true circumcision." 44 Consequently, this metaphorical ritual is critical for Barnabas and his hearers, compelling a closer investigation into the relationship between the epistle and rituals in general.

${ }^{41}$ Though Martin B. Shukster and Peter Richardson also interpret 16.10 as a critical verse, representing the convergence of the two major themes of the letter, they see the themes as being different, i.e., the temple and the birkat ha-minim ("Temple and Bet Ha-midrash"; see also Peter Richardson and Martin B. Shukster, "Barnabas, Nerva, and the Yavnean Rabbis," JTS 34 [1983] 31-55); however, Richardson and Shukster's argument for the rebuilding of the temple by Nerva is tenuous. They base it on Nerva's coin, which does not necessarily have to mean what they suggest, and they also base it on the historically suspicious account of Gen. Rab. 64.8; also Emil Schürer, The History of the Jewish People in the Age of Jesus Christ (175 B.C.-A.D. 135) (ed. Géza Vermès and Fergus Millar; 3 vols.; Edinburgh: T\&T Clark, 1973) 1:535 (though Richardson and Shukster acknowledge this and also cite texts from the Megillat Ta 'anit). For a recent analysis of Richardson and Shukster's hypothesis, see Carleton Paget, Epistle of Barnabas, 15-17; concerning Richardson and Shukster's suggestion of the birkat ha-minim, recent research has questioned the direct influence that the birkat ha-minim had on "Christians" in the Diaspora cities, e.g., Jonathan Bernier, Aposynagogos and the Historical Jesus in John: Rethinking the Historicity of the Johannine Expulsion Passages (BibInt 122; Leiden: Brill, 2013) 40-41-though Richardson and Shukster place the provenance of Barnabas in Syria. However, Richardson and Shukster's observations of Barnabas's responding to the birkat ha-minim via his exegesis can also be explained through the arguments proposed in this study.

${ }^{42}$ Scholarship on early Christianity has also mentioned, but not explored, this connection, e.g., Stroumsa, "Early Christianity," 165, 172; idem, Making of the Abrahamic Religions, 39; Brakke, "Canon Formation and Social Conflict," 403, 408. See Newman (Before the Bible), however, for this exploration in early Judaism.

${ }^{43}$ The argument is not that this metaphor was an actual ritual that took place in a social context, but that it addresses the most primary communal needs that are typically addressed by rituals. In short, it functions as a ritual. See the next section for more details.

${ }^{44}$ Shukster and Richardson, "Temple and Bet Ha-midrash," 29. 


\section{Rituals}

\section{A. Deconstruction or Destruction of Rituals?}

For most, if not all, of the Jewish communities of Second Temple Judaism, rituals were particularly important. Shaye J. D. Cohen has argued that religion in the ancient world was not primarily based on faith or dogma, but practices, commandments, acts, and other customs. Accordingly, the boundary lines between Jews and gentiles were drawn mostly on differing observances ${ }^{45}$ Cohen writes: "For the polytheists of the Greco-Roman world, the most characteristic features of Judaism were, aside from circumcision, the observance of the Sabbath and the abstention from pork." ${ }^{46}$ This description is corroborated by the oft-quoted texts from writers like Juvenal (Sat. 14.96-106), Suetonius (Dom. 12.2), and Tacitus (Hist. 5.5.1-2). If one, like Barnabas, seeks to destroy this strand of Judaism, then one must attack its foundational practices - or, in this context, rituals. ${ }^{47}$ That Barnabas does so is readily apparent even at a cursory skim of the letter. This has led Geoffrey D. Dunn, following Pierre Prigent, to suggest that perhaps Barnabas is more anti-cultic than anti-Judaic. ${ }^{48}$ Barnabas can be seen as one who deconstructs Judaism, but his opprobrium against rituals cuts both ways. If Barnabas deconstructs Judaism and its rituals, then in what ways does he (ironically) advance his own ritual(s)? Is it possible for Barnabas to create a community that is devoid of any ritual ${ }^{49}$

${ }^{45}$ Of course, Cohen does not mean to say that the Jews did not have any faith or beliefs (From the Maccabees, 51-52); George W. E. Nickelsburg says that the difference between "Jews" and "Christians" was "christological." However, Nickelsburg also says that "For Jews, the right life was bound up with the observance of the Torah" (Ancient Judaism and Christian Origins: Diversity, Continuity, and Transformation [Minneapolis: Fortress, 2003] 60). See also Daniel Boyarin, Border Lines: The Partition of Judaeo-Christianity (Divinations; Philadelphia: University of Pennsylvania Press, 2004) 10.

${ }^{46}$ Cohen, From the Maccabees, 65; however, see Cohen's more detailed treatment that assesses circumcision, language, and social mechanisms, particularly in the setting of Diaspora Jews, where he concludes: "the diaspora Jews of antiquity were not easily recognizable, if, indeed, they were recognizable at all” (“"Those Who Say They Are Jews and Are Not': How Do You Know a Jew in Antiquity When You See One?" in Diasporas in Antiquity [ed. Shaye J. D. Cohen and Ernest S. Frerichs; Atlanta: Scholars Press, 1993] 1-45, at 39); J. Z. Smith also argues that circumcision was not reliably a central mark for a Jew, since many other groups, especially the Egyptians, were also circumcised (Barn. 9.6). Smith rather sees that the association to the synagogue was the most prominent marker based on funeral inscriptions ("Fences and Neighbors: Some Contours of Early Judaism," in Approaches to Ancient Judaism: Theory and Practice [ed. William Scott Green; Missoula, MT: Scholars Press, 1978] 2:1-25).

${ }^{47}$ By rituals, I am referring to sacrifices, fasting, circumcision, and Sabbath; I am not arguing that abstention from pork - though Barnabas addresses this (10.3) - should be considered a ritual.

${ }^{48}$ Geoffrey D. Dunn, "Tertullian and Rebekah: A Re-Reading of an 'Anti-Jewish' Argument in Early Christian Literature," VC 52 [1998] 119-45, at 140; Pierre Prigent, Les Testimonia dans le christianisme primitif: l'Épitre de Barnabé I-XVI et ses sources (Paris: Gabalda, 1961) 29-83.

${ }^{49} \mathrm{In} 11.11$, Barnabas does make a reference to baptism, but it is difficult to see if this is performed in a way that would make this ritual different than that from Jewish traditions. 


\section{B. Rituals and Social Distinctions}

According to most ritual theorists, the answer is negative. Rituals are needed for group identity because they address the group's need for social and ideological distinctions. Concerning the former, Richard Jenkins argues that group identity is reducible to (1) demarcating external boundaries to distinguish the group from the other as well as (2) defining internal hierarchies to create group roles. Jenkins locates rituals as the means that allow groups to make these necessary external and internal distinctions, distinctions that can be categorized as social. ${ }^{50}$

Although Barnabas appears to reject rituals when compared with most groups of Judaism at this time, Barnabas is clearly attempting to generate these external and internal differences that are not only integral for group formation but that are accomplished through rituals. Efforts to differentiate externally and internally recur throughout the epistle through Barnabas's "us"-and-"them" language along with the frequent reminders of Barnabas's pedagogical role $(1.5,8 ; 4.6 ; 6.9 ; 7.1 ; 8.2 ; 9.7$, $9 ; 10.11 ; 12.3,8 ; 14.4 ; 15.5 ; 16.7,8 ;$ ch. $17 ; 18.1)$. Circumcision of hearing is able to make both of these social distinctions. Externally, circumcision is a covenantal sign that separates "us" from "them." Internally, if Barnabas is the one with the true $\gamma v \tilde{\omega} \sigma 1 \varsigma$ that his recipients need to hear, then he is clearly setting his role apart from the rest of the group. ${ }^{51}$ Hence, we see that not only does circumcision of hearing function as a ritual because of its repeated references with causal implications (i.e., more than a mere analogy), but because it creates the social distinctions that every group needs.

\section{Rituals and Ideological Distinctions}

Groups also need to create ideological distinctions. This point has already been mentioned in the above discussion on canon, but what has not been underscored is the role that rituals play in this regard. It is often quoted that "Ritual is, above all, an assertion of difference," but it is important to recognize that in the fuller context of this quotation, the difference is more ideological than social—or, as $\mathrm{J}$.

\footnotetext{
${ }^{50}$ Richard Jenkins, Social Identity (rev. ed.; New York: Routledge, 2008) 169-83; for more on the latter point, see Catherine M. Bell, Ritual Theory, Ritual Practice (rev. ed.; New York: Oxford University Press, 2009) 102.

${ }^{51}$ For a discussion on the student-teacher emphasis in early Christianity, particularly in Egypt (the likely provenance of Barnabas), see Brakke, "Canon Formation and Social Conflict," 400-403. Brakke is influenced by Hans von Campenhausen, who reconstructs the student-teacher emphasis primarily through Clement of Alexandria because there is no other textual evidence on this topic (Ecclesiastical Authority and Spiritual Power in the Church of the First Three Centuries [trans. J. A. Baker; London: Black, 1969] 195-211), though he does mention Barnabas (ibid., 192-95). I would contend, however, that the student-teacher emphasis can be traced earlier to Barnabas himself when examining the circumcision of hearing motif through canon and ritual, especially considering the close relationship between Barnabas and Clement (at least on ideological grounds) as mentioned in nn. 35-37 above.
} 
Z. Smith describes it, the " "gnostic' dimension to ritual." ${ }^{52}$ Smith's reference to "gnostic" is significant as it implies that rituals have the ability to convey some kind of knowledge. Thus, we see more clearly the intricate relationship between canon and ritual. In other words, groups are formed around principles, as prescribed by their canon, that are expressed and understood through rituals. Rituals, therefore, "are more likely to serve as the foundation ... of the community's identity" 53 as they constitute "a powerful and visible embodiment of the abstraction of collective identity." ${ }^{54}$

This convergence between canon and ritual that is required for communal identity is what makes the metaphor of the circumcision of hearing an apt one. To put it simply, ears and hearing would correlate to the gnostic or canonical dimension, while circumcision would correlate with the ritualized dimension. This suggests that Barnabas is not rejecting rituals in their entirety but only certain types. Because circumcision of hearing has epistemological or hermeneutical implications, it satisfies Barnabas's need for some kind of a ritual and provides an explanation for why some people have not fully submitted to his teachings. More specifically, what will be examined below is how Barnabas perceives his hearers now that their ears have been circumcised. On the one hand, the purpose of their circumcision was for them to be able to believe and to understand $(9.3 ; 10.12)$. On the other hand, Barnabas continually implies that his hearers do not yet truly believe and understand, even though it appears that this circumcision took place in the past. In fact, it is because of this delicate tension that this metaphorical ritual is most suitably described as circumcision. ${ }^{55}$

\section{The Tension of Barnabas's Hearers}

According to Barnabas, the baseline for proper believing and understanding is found in the prophets - such as Moses $(4.8 ; 10.1 ; 14.3)$, David (12.10; 13.10), and Abraham (9.8; 13.7) — and, unsurprisingly, himself $(1.4,5 ; 6.5 ; 17.1-2)$. Such unqualified attribution of knowledge and faith is not given to his hearers. Although Barnabas writes that "a great faith and love dwell within [them]" (1.4), he continues in the next line that he had "hastened ... to send [them] a brief letter, that [they] may have perfect knowledge to accompany [their] faith" (1.5). Elaborating further on their faith, Barnabas mentions that it "will be of no use to us if we do not stand in resistance" (4.9). In other words, though his hearers have a degree of knowledge and faith, Barnabas later reveals that " "perfect knowledge' is lacking." ${ }^{.56}$ Barnabas

\footnotetext{
${ }^{52}$ Jonathan Z. Smith, To Take Place: Toward Theory in Ritual (Chicago: University of Chicago Press, 1987) 109.

${ }^{53}$ David Manier and William Hirst, “A Cognitive Taxonomy of Collective Memories," in Cultural Memory Studies (ed. Nünning, Erll, and Young) 253-62, at 251.

${ }^{54}$ Jenkins, Social Identity, 177.

${ }^{55}$ This point does not take away from the more obvious reason that Barnabas phrased this metaphorical ritual as circumcision, which is to subvert the literal practice of circumcision.

${ }^{56}$ Wengst, Tradition, 113: "vollkommene Erkenntnis" fehlt ihnen.
} 
still has urgency for them to increase their knowledge and faith, and, as it currently stands, their faith is vain unless they are able to stand in resistance.

In other instances, Barnabas claims that "we" have the true understanding. Despite the rhetoric, what he really means is that only he himself is presently privileged with this wisdom. This is most evident when he makes the claim that "the Master has made known to us what has happened and what now is" (1.7); however, the ensuing verse makes a counterclaim as Barnabas has the need to "show a few matters to [them]" in order that they "will gladden [their] hearts in the present circumstances" (1.8). There are, additionally, scattered references to what is currently transpiring and, in each of these references, Barnabas finds the need to explain the significance of these events (e.g., 5.3; 6.19; 8.7; 16.4, 5). Similarly, Barnabas expresses gratitude to the Lord because he has "placed the wisdom and knowledge of his secrets within us" (6.10). Their wisdom and knowledge, however, are nonetheless lacking, as he later makes explicit (ch. 17). This point is also implied throughout the entire letter: citation after citation and explanation after explanation only cement the current wisdom and knowledge of Barnabas, not that of his hearers.

Barnabas also expresses urgency - or even uncertainty - about his readers' ability to understand and believe, despite his allusions to the circumcision of hearing. Though circumcision is intended so that they might understand and believe, nowhere does Barnabas actually state that they are presently understanding and believing (with the exception of 16.7). ${ }^{57}$ The mood for all of the verbs related to understanding and believing, when referring to the recipients, is either subjunctive or infinitive; these verbs are not used to convey the present reality of the recipients (though 3.6 is an indicative of $\pi 1 \sigma \tau \varepsilon v \omega \omega$, this is in the future tense).

Barnabas does, however, use similar verbs in the imperative mood or in

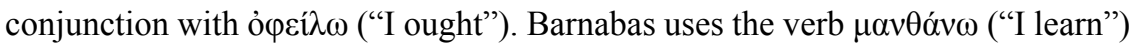
nine times, seven of which are used in the second person imperative (e.g., 5.5; 6.9; $9.7,8 ; 14.4 ; 16.2,7) .{ }^{58}$ The verb ópcí $\lambda \omega$ is also used frequently $(2.1,9,10 ; 4.6 ; 6.18$; 13.3), but what is significant about Barnabas's usage is how it is supplemented with an epistemological verb, usually $\alpha i \sigma \theta \alpha \dot{v o} \mu \alpha \mathrm{l}$ ("I am aware"). ${ }^{59}$ On the one hand,

${ }^{57}$ There is a total of eight instances of $\pi 1 \sigma \tau \varepsilon v \omega$ and six of them are used with the recipients as the subject $(7.2 ; 9.3 ; 16.7$; implied subject, $3.6 ; 6.3 ; 7.2)$. There is a total of seven instances of

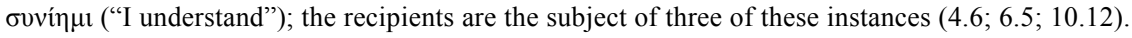

${ }^{58}$ By contrast, the New Testament does not use $\mu \alpha v \theta \alpha \dot{v} \omega$ in the second person imperative in any of the epistles. This form of the verb is only found in Jesus's sayings (Matt 9:13, 11:29, 24:32; Mark 13:28). Perhaps it is only coincidental, but it is worth mentioning that these imperatives are used multiple times in the epistle's more controversial discussions of circumcision (ch. 9) and the temple (ch. 16), which strengthens Daniel Schwartz's hypothesis on how Hadrian's policies may have instigated the Bar Kokhba revolt (Studies in the Jewish Background, 147-53). For an alternative view on this topic, see Giovanni Battista Bazzana, "The Bar Kokhba Revolt and Hadrian's Religious Policy," in Hadrian and the Christians (ed. Marco Rizzi; Millennium-Studien 30; Berlin: de Gruyter, 2010) 85-110.

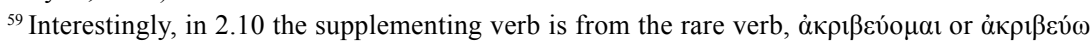
("I pay strict attention"). 
these imperatival expressions imply, to a certain degree, Barnabas's confidence that his hearers can fulfill what is being requested of them; on the other hand, these expressions imply the need for Barnabas to be particularly pointed in his teachings as if to sear them into their minds.

There are still further indications that the recipients are not fully understanding what Barnabas has to say when we examine his rhetoric. The rhetoric is used in two ways: (1) Barnabas postures himself as one who is humble and genuine, and (2) he positions himself as one with superior knowledge. In the former, such rhetoric is often employed to accompany one of his (many) injunctions for the recipients to accept his teaching. Followed immediately after one of these injunctions that they "should understand," he softens the tone by saying, "I am asking you this as one who is from among you and who loves each and every one of you more than my own soul" (4.6). Just a few verses later, he says, "I hasten to write, as your lowly scapegoat. Therefore, we should pay close attention here in the final days" (4.9). Almost verbatim, Barnabas adds: "I am a lowly scapegoat for your love" after he expresses his desire for them to "understand" (6.4; also 1.8). When considering only this first use of his rhetoric, it is tempting to conclude that Barnabas has doubts about his own teachings and $\gamma v \tilde{\sigma} \sigma ı \varsigma$.

However, Barnabas's first rhetorical strategy should be balanced by, if not interpreted through, his claims that he possesses superior knowledge. That is, Barnabas's self-perception is more likely to be the one of a wise teacher than a lowly scapegoat. In fact, Barnabas mentions frequently that his teachings have already been revealed (e.g., $1.7 ; 3.6 ; 5.3 ; 6.7,12 ; 7.1 ; 11.1$ ), so the fact that his hearers fail to understand fully is not an indictment on his part. But Barnabas does not put the blame solely on his hearers. After one of the more strained interpretations offered by Barnabas (i.e., his usage of the nomina sacra in 9.8), he is compelled further to substantiate his creative assertion by writing: "No one has learned a more reliable lesson from me. But I know that you are worthy" (9.9). Here, Barnabas is saying two things that correspond to his twofold rhetorical strategy: his teachings are reliable and his recipients are worthy. It is likely that Barnabas is more convinced of the former than the latter. For instance, Barnabas also mentions twice that he is holding back on his superior teaching because he is afraid that his hearers will not be able to understand: "I am writing to you in very simple terms, that you may understand" (6.5; also 17.2). Are these indications that Barnabas doubts the ability of his hearers to understand his teachings? Or is Barnabas concerned that his hearers are unwilling to agree with his $\gamma v \tilde{\omega} \sigma ı \varsigma$ ? If so, then how can we reconcile these possibilities with the fact that the hearing of his hearers has already been circumcised $(9.3 ; 10.12)$ ? 


\section{E. Circumcision Producing Liminality}

Such a paradox corresponds to Victor Turner's model of liminality. ${ }^{60}$ Turner developed this notion within the context of Arnold van Gennep's threefold phase of rites of passage (i.e., separation, margin/liminality, and aggregation). ${ }^{61}$ Based on his studies on the Ndembu tribe of Zambia, Turner observed that after initiatory rites such as circumcision, neophytes are placed in a fragile phase that is marked by the kind of inconsistency that has been outlined above. Turner observes that "in some boys' initiations, newly circumcised boys are explicitly likened to menstruating women." ${ }^{2}$ The neophytes in this transitory phase are thus "neither living nor dead from one aspect, and both living and dead from another. Their condition is one of ambiguity and paradox, a confusion of all the customary categories." ${ }^{63}$

In the context of Barnabas, we see that though Barnabas regards circumcision as already "performed" in the past, there is no evidence that his hearers have reached their final phase of aggregation - the ability to believe and understand properly. This is not because Barnabas doubts his own teaching. Nor is it because his hearers are unwilling to listen or unable to understand. When considering how initiatory rites typically create a state of liminality, the likelier explanation for why Barnabas writes the way that he does is that he is aware of the recipients' vulnerable state. They are impressionable to both Barnabas's own teachings as well as the deleterious teachings of others $(2.9,10 ; 4.6,14 ; 16.1) \cdot{ }^{64}$ In short, Barnabas is certain of the truthfulness of his own teachings, but shows concerted effort to ensure that his hearers are able to understand and believe his teachings because of the initiatory condition of his hearers. ${ }^{65}$ Turner's observations are once again pertinent:

The arcane knowledge or "gnosis" obtained in the liminal period is felt to change the inmost nature of the neophyte, impressing him, as a seal impresses

${ }^{60}$ Victor Turner, The Forest of Symbols: Aspects of Ndembu Ritual (rev. ed.; Ithaca, NY: Cornell University Press, 1970) 93-111; an updated version of Turner's chapter can be found in idem, The Ritual Process: Structure and Anti-Structure (rev. ed.; Lewis Henry Morgan Lectures 1966; New Brunswick, NJ: Aldine Transaction, 2007).

${ }^{61}$ Turner, Forest of Symbols, 94; Arnold van Gennep, The Rites of Passage (rev. ed.; New York: Routledge, 2010).

${ }^{62}$ Turner, Forest of Symbols, 96.

${ }^{63}$ Ibid., 96-97. This fragile state is portrayed in Gen 34.

${ }^{64}$ This explains why there are other instances in the letter where Barnabas does not view his hearers as full members of the group that he is trying to construct. Barnabas's thoroughly didactic explanations on why some of the "fundamental" practices of the other are misguided all imply that his hearers were tempted to engage in these practices, if not already engaged in them (e.g., sacrifice in 2.4-10, fasting in 3.1-5, circumcision in 9.6, and the Sabbath in 15.1-9; the need for Barnabas to distinguish his hearers from the other in $4.6 ; 13.1-7 ; 14.1-9)$. The notion of liminality also explains why Barnabas outlines the basics of salvation (17.1) yet insinuates that there is still more to learn (17.2). See also Derry, "One Stone on Another," 528; Dunn, "Tertullian and Rebekah"; Janni Loman, "The Letter of Barnabas in Early Second-Century Egypt," in The Wisdom of Egypt: Jewish, Early Christian, and Gnostic Essays in Honour of Gerard P. Luttikhuizen (ed. Anthony Hilhorst and Geurt Hendrik van Kooten; AGJU 59; Leiden: Brill, 2005) 247-66; Lanfranchi, "Attitudes to the Sabbath."

${ }^{65}$ This emphasis is therefore a nuance to the interpretations of Julien Smith and Hvalvik (see n. 26). 
wax, with the characteristics of his new state. It is not a mere acquisition of knowledge, but a change in being. His apparent passivity is revealed as an absorption of powers which will become active after his social status has been redefined in the aggregation rites. ${ }^{66}$

Once again, we see the connection between ritual and gnosis, but we also gain a new perspective on what was previously observed about Barnabas's choice of verbs, especially in the imperatival sense. In essence, Barnabas is seeking to impress upon his hearers "as a seal impresses wax." Hearing the epistle should not be understood as "mere acquisition of knowledge, but a change in being,"


Barnabas is quite forthcoming that the purpose of his writing is "that you may

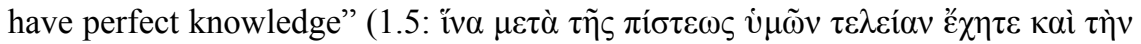
$\gamma v \tilde{\omega} \sigma(\varsigma)$, it is significant that, toward the end of the letter, he writes, "we maintain

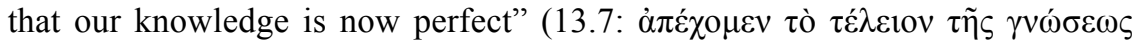
$\dot{\eta} \mu \tilde{\omega} v) .{ }^{67}$ The placement of these two statements and their syntactical agreement indicate Barnabas's hope that he had impressed "arcane knowledge or 'gnosis", upon his neophytes. ${ }^{68}$

${ }^{66}$ Turner, Forest of Symbols, 102 [italics in original].

${ }^{67}$ Carleton Paget regards the syntactical relationship to be "surely significant," (Epistle of Barnabas, 165); see also Kraft, Barnabas and the Didache, 23.

${ }^{68}$ While it is beyond the scope of this study, it would be worthwhile to explore whether the "reading event" of the Epistle of Barnabas itself can be construed as a ritual, particularly in light of Catherine Bell's flexible ritualization framework and the findings in ancient book culture (Ritual Theory, Ritual Practice; for the phrase "reading event," see William A. Johnson, "Toward a Sociology of Reading in Classical Antiquity," AJP 121 [2000] 593-627, at 602 n. 20). If so, then I suggest that at least the following four topics should be examined (to keep this note at a manageable length, I am only citing the most recent studies). First, research in the epistle has understood the Two Ways section (Barn. 18-21) as having a ritualized, if not catechetical, function, particularly with the parallels with 1QS 3.13-4.27 and the Didache (Robert A. Kraft, "Early Developments of the "Two-Ways Tradition[s]," in For a Later Generation: The Transformation of Tradition in Israel, Early Judaism, and Early Christianity [ed. Randal A. Argall, Beverly Bow, and Rodney Alan Werline; Harrisburg, PA: Trinity, 2000] 136-43; Jonathan A. Draper, "Vice Catalogues as Oral-Mnemonic Cues," in Jesus, the Voice, and the Text: Beyond the Oral and the Written Gospel [ed. Tom Thatcher; Waco, TX: Baylor University, 2008] 111-33; James N. Rhodes, "The Two Ways Tradition in the Epistle of Barnabas: Revisiting an Old Question," CBQ 73 [2011] 797-816; Smith, "Epistle of Barnabas"). Second, the location of the Diaspora synagogue as being the ideal place where ritual and canonical interpretation converge (Lee I. Levine, The Ancient Synagogue: The First Thousand Years [rev. ed.; New Haven: Yale University Press, 2005] 155; Nickelsburg, Ancient Judaism, 157), as well as being open to those of "different religio-political outlooks" (Anders Runesson, Donald D. Binder, and Birger Olsson, The Ancient Synagogue from Its Origins to 200 C. E.: A Source Book [AGJU 72; Leiden: Brill, 2008] 3; see also Erich S. Gruen, Diaspora: Jews Amidst Greeks and Romans [Cambridge: Harvard University Press, 2002] 113; Cohen, From the Maccabees, 47). Third, the recent findings on ancient book culture, which was not only pervasive among the elite (William A. Johnson, Readers and Reading Culture in the High Roman Empire: A Study of Elite Communities [Classical Culture and Society; New York: Oxford University Press, 2010]), but was appropriated in many ways by the early Christ movement (Gregory P. Fewster, "Ancient Book Culture and the Literacy of James: On the Production and Consumption of a Pseudepigraphal Letter," ZAC 20 [2016] 387-417); more generally the sociocultural implications of reading, which includes its ability to 


\section{Conclusion}

For Barnabas, his means of initiating the members of his community is through the circumcision of hearing $(8.7 ; 9.3 ; 10.12 ; 16.10)$. This circumcision enables his hearers to deconstruct past interpretations, interpretations that will bring "error in through the backdoor" (2.10) so that they can orient themselves around Barnabas's canonical interpretation. In this way, the circumcision makes external distinctions between "us" and "them," as well as an internal distinction (i.e., Barnabas is the possessor of $\gamma v \tilde{\omega} \sigma 1 \varsigma$ while his hearers are dependent upon him). Despite these distinctions, there is still ambiguity as Barnabas's hearers are not yet able to fully grasp his $\gamma v \tilde{\omega} \sigma \mathrm{s} \varsigma$ because they are in the vulnerable state of liminality wherein the present circumstances are difficult to discern (1.8). Hence, Barnabas writes in such a way as to impress his "arcane knowledge and 'gnosis" " onto his hearers, ${ }^{69}$ leading them to become $\tau$ òv $\lambda \alpha$ òv $\tau$ òv Kaıvòv of God, which will not be fulfilled until the "eighth day" $(6.19 ; 15.7-9 ; 16.8-9)$.

This study has therefore sought to make a significant contribution to scholarship on both the Epistle of Barnabas in particular as well as group dynamics and early Jewish-Christian relations in general. At the most granular level, the allusions to the circumcision of hearing are shown to be placed at key points within the letter $(8.7 ; 9.3 ; 10.12 ; 16.10)$. By illustrating the critical importance that this metaphorical ritual has in the text, this study addresses a lacuna in the scholarship on the epistle as sustained analysis on this matter has been wanting. More broadly, this study offers a richer picture of the liminality of the community that Barnabas was attempting to construct and maintain. While Ferdinand R. Prostmeier is generally correct to assert that "the anti-Judaism of Barn is inner-Christian polemics," much of the social analysis on the letter has focused on the intergroup dynamics, namely its relation to Judaism. ${ }^{70}$ This study, on the other hand, reconstructs the fragile dynamics from a more intragroup standpoint. ${ }^{71}$ Concerning the impact on the general area of early

construct meaning and value for a particular group (Johnson, Readers and Reading Culture, 3-16). Finally, the theoretical tools to explore the performative aspects of texts (John R. Searle and Daniel Vanderveken, "Speech Acts and Illocutionary Logic," in Logic, Thought and Action [ed. Daniel Vanderveken; Logic, Epistemology, and the Unity of Science 2; Dordrecht: Springer, 2005] 109-32) and how they relate to rituals in particular (Roy A. Rappaport, Ritual and Religion in the Making of Humanity [Cambridge: Cambridge University Press, 1999]); Paul Connerton's observation is especially applicable for Barnabas with the mutual emphasis on the use of personal pronouns (i.e., "us" versus “them") (How Societies Remember [Cambridge: Cambridge University Press, 1989] 58).

${ }^{69}$ Turner, Forest of Symbols, 102 [italics in original].

${ }^{70}$ Ferdinand R. Prostmeier, "Antijudaismus im Rahmen christlicher Hermeneutik: zum Streit über christliche Identität in der Alten Kirche Notizen zum Barnabasbrief," ZAC 6 (2002) 38-58, at 56: "Der Antijudaismus des Barn ist innerchristliche Polemik" [italics in original]. The intergroup emphasis can be seen in the studies of Derry ("One Stone on Another") and Kok ("True Covenant People"; note, however, Kok's hypothetical qualification in ibid., 88).

${ }^{71}$ While Julien Smith does touch upon the intragroup dynamic, he focuses mostly on the teaching authority - or, canonical interpretation - of Barnabas ("Epistle of Barnabas") whereas the present study is focused more on the liminality of Barnabas's hearers as well as providing a sustained examination on the circumcision of hearing with more conceptual depth. 
Jewish-Christian relations, the methodological approach taken in this study-which provides a more theoretical articulation on the key constituents of a communal group, that is, canon and ritual — presents analytical constructs to help explore this contentious topic in new and penetrating ways. ${ }^{72}$

Lastly, the utilization of cross-cultural and interdisciplinary studies allows modern (and mostly Western) scholars to see the rationale behind the oddities that have been well expressed in Barnabas scholarship. ${ }^{73}$ By interpreting the letter along more conceptually thoughtful formulations on canon and ritual, it has been argued that what Barnabas was attempting to do is not different from what takes place in every communal group even in our present societies. Within the convergence of canonical interpretation and ritual performance, certain aspects of the strangeness of Barnabas begin to fade away. Even in modern times, blockbuster hits in the entertainment industry promise either a glimpse toward the future or a privileged perspective into the past. ${ }^{74} \mathrm{It}$ is likewise difficult to decide which question is most frequent at the water cooler: "how was your weekend?" or "do you have any plans this weekend?" Outside of our modern, Western culture, familial lineage is critical, as is one's posterity. For Barnabas, this tension "betwixt and between" "75 interpreting the past and creating a future is not only vital for his theology, but for the power of his rhetoric: his assertions are persuasive because they generate claims where "such possibilities cannot be realized" interpretations of the past must be overhauled with Barnabas's new $\gamma v \tilde{\omega} \sigma \mathrm{s} \varsigma$ - another example of how "the crucial issue is not history but hermeneutics." hand, Barnabas concedes that contemporaneous circumstances present paradoxes to his $\gamma v \tilde{\omega} \sigma 1 \varsigma$, but this is only because his community is still in the liminal state. It is also because he and his community have not yet experienced their new creation status (6.19), and because the true Sabbath is on the always-future eighth day (15.7-9), and because the temple is still being built (16.8-9), and so on. ${ }^{78}$ In the interim, Barnabas and his community can find refuge in the fact that "Texts construct a world," a world which "authors and readers already inhabit and experience as

${ }^{72}$ See nn. 2 and 3.

${ }^{73}$ See n. 1.

${ }^{74}$ See also Marco Cinnirella's study on how social identity is usually based on the re-interpretation of the past as well as the shaping of the future ("Exploring Temporal Aspects of Social Identity: The Concept of Possible Social Identities," European Journal of Social Psychology 28 [1998] 227-48). For this similar, temporal concept, see Smith, To Take Place, 109-12.

${ }^{75}$ Turner, Forest of Symbols, 96.

${ }^{76}$ Smith, To Take Place, 109. For a cognitive-scientific standpoint on the power of religious claims, see Richard Sosis, “The Adaptive Value of Religious Ritual," American Scientist 92 (2004) $166-72$, at 172.

${ }^{77}$ Shaye J. D. Cohen, The Beginnings of Jewishness: Boundaries, Varieties, Uncertainties (Berkeley: University of California Press, 1999) 349.

${ }^{78}$ One might view this reference to liminality to be different than the more hermeneutical one mentioned earlier in this present study. A closer reading of the letter, however, suggests that this distinction does not exist for Barnabas since elsewhere he conflates the more eschatological or newcreational quality with the more hermeneutical or epistemological quality (Barn. 6.10-19; 16.6-9). 
'reality" "79-where "our knowledge is now perfect" (13.7) and where "God truly resides within our place of dwelling — within us" (16.8), in other words, where "the imagined ceases to be imaginary." $" 80$

${ }^{79}$ Lieu, Christian Identity, 61.

${ }^{80}$ Jenkins, Social Identity, 177. 